\title{
Karakter Morfologi dan Produktivitas Kultivar Rumput Benggala (Panicum maximum) pada Tanah Kering Masam
}

\section{Morphological Characters and Productivity of Benggala Grass (Panicum maximum) Cultivars on Acid Dry Soils}

\author{
Achmad Fanindi*, Sajimin, dan Endang Sutedi \\ Balai Penelitian Ternak Ciawi Bogor \\ Jl. Veteran 3 Ciawi, Bogor 16720, Jawa Barat, Indonesia \\ Diterima 18 Mei 2020/Disetujui 22 Juli 2020
}

\begin{abstract}
Benggala grass (Panicum maximum) is a forage that is widely used by farmers in Indonesia. Forage cultivation could be carried out in suboptimal land. Acid dry land is one type of suboptimal land that is widely available in Indonesia. This study aimed to elucidate the morphological characteristics and productivity of Benggala grass in acid dry soils. The study was conducted in the greenhouse of the Research Institute of Animal Production for 10 months, using three Benggala grass cultivars (Petrie, Gatton, and Natsuyutaka). The cultivars were planted in two types of soil, acid ( $p H 4.5)$ and not acid soil (pH $7.10)$ in a $40 \mathrm{~cm}$ diameter pot. The experimental design was a factorial completely randomized design with 10 replications. The first factor was the type of soil and the second factor was the cultivar of Benggala grass. The observed variables were morphological characters, flowering age, seed production, and forage production. The results showed that morphological characters such as leaf length, length of internode, stem diameter, length of flower were influenced by cultivars type $(P<0.05)$ and were not affected by soil type $(P>0.05)$. Grass productivity was influenced by soil type $(P<0.05)$. The productivity of all cultivars tested declined on acid soils so that they were categorized as intolerant cultivars to acid soils. Therefore, it is necessary to conduct breeding activities to obtain acid tolerant Benggala grass cultivars.
\end{abstract}

Keywords: forage, production, suboptimal

\section{ABSTRAK}

Rumput benggala merupakan tanaman pakan ternak (TPT) yang banyak digunakan oleh peternak di Indonesia. Pengembangan budidaya TPT selalu diarahkan pada lahan marjinal atau sub optimal. Lahan kering masam merupakan lahan marjinal yang cukup luas di Indonesia. Tujuan penelitian ini adalah untuk melihat karakter morfologi dan produktivitas kultivar rumput benggala di tanah kering masam. Penelitian dilakukan di rumah kaca Balai Penelitian Ternak Ciawi selama 10 bulan, menggunakan tiga kultivar rumput benggala (kultivar Petrie, Gatton dan Natsuyutaka). Kultivar tersebut ditanam di dua jenis tanah yaitu tanah kering masam (pH 4.5) dan tidak masam (pH 7.10) pada pot berdiameter $40 \mathrm{~cm}$ dan tinggi 30 $\mathrm{cm}$. Rancangan percobaan adalah rancangan acak lengkap faktorial dengan 10 ulangan. Faktor pertama adalah jenis tanah dan faktor kedua adalah kultivar rumput benggala. Peubah yang diamati yaitu karakter morfologi, umur berbunga, produksi biji dan produksi hijauan. Hasil penelitian menunjukan bahwa karakter morfologi seperti panjang daun, panjang ruas, diameter batang, panjang bunga dipengaruhi oleh jenis kultivar $(P<0.05)$ dan tidak dipengaruhi oleh jenis tanah $(P>0.05)$. Produktivitas rumput dipengaruhi jenis tanah $(P<0.05)$. Produktivitas semua kultivar rumput benggala yang diuji menurun pada tanah kering masam, sehingga dikategorikan sebagai kultivar tidak toleran terhadap lahan kering masam. Oleh karena itu, perlu dilakukan kegiatan pemuliaan untuk memperoleh kultivar rumput benggala toleran di lahan kering masam.

Kata kunci: produksi, suboptimal, tanaman pakan

\section{PENDAHULUAN}

Tanaman pakan merupakan sumber hijauan yang diperlukan oleh ternak ruminansia. Kebutuhan

\footnotetext{
* Penulis untuk korespondensi. e-mail: afanindi@gmail.com
}

hijauan meningkat seiring meningkatnya jumlah ternak ruminansia, sehingga perlu meningkatkan produktivitas tanaman pakan ternak (TPT). Salah satu kendala dalam peningkatan produktivitas TPT adalah terbatasnya lahan untuk pengembangan TPT. Lahan yang disediakan untuk pengembangan TPT sebagaian besar adalah lahan suboptimal. 
Lahan suboptimal yang dapat digunakan adalah lahan kering masam, karena luas lahan ini di Indonesia sekitar 108,8 juta ha, dan 62,6 juta ha berpotensi sebagai lahan pertanian (Mulyani dan Sarwani, 2013). Namun demikian, pengembangan TPT pada lahan ini dibatasi beberapa faktor, diantaranya memiliki $\mathrm{pH}$ tanah rendah dengan kejenuhan Alumunium (Al) yang tinggi (Efendi et al., 2015), sehingga menyebabkan terhambatnya pertumbuhan dan fungsi akar (Xu et al., 2018), mempengaruhi fotosintesis dan level hormon (Yang et al., 2012), menghambat pertumbuhan tanaman dan mengurangi hasil panen (Kochian et al., 2005). Pendekatan yang bisa dilakukan untuk pengembangan TPT di lahan ini, adalah melalui teknologi pemupukan, pengapuran dan pengelolaan bahan organik serta penggunaan varietas TPT yang toleran (Fanindi et al., 2019). Penggunaan varietas toleran diharapkan dapat meningkatkan produksi tanaman dan menghasilkan sifat-sifat unggul lainnya (Mulyaningsih et al., 2016).

Rumput benggala (Panicum maximum) merupakan salah satu TPT yang berpotensi untuk dikembangkan sebagai sumber hijauan ternak ruminansia. Produksi rumput benggala yang mendapat pemupukan $\mathrm{N}$ bisa mencapai 18.4 -20.9 ton bahan kering (BK) ha ${ }^{-1}$ per tahun (Fernandes et al., 2014), proposi daun dibandingkan batangnya adalah 73$75 \%$ pada musim hujan dan $81-87 \%$ pada musim kemarau (Hare et al., 2014). Rumput ini juga memiliki kualitas nutrisi yang tinggi, beradaptasi pada tanah dengan tingkat kesuburan medium dan curah hujan diatas 600 mm (Jank et al., 2010). Keunggulan rumput ini perlu diuji pada lahan kering masam, karena produktivitasnya di lahan ini menunjukkan hasil yang bervariasi (Almeida et al., 2000).
Tujuan penelitian ini adalah untuk mengetahui karakter morfologi dan produktivitas beberapa kultivar rumput benggala di tanah kering masam.

\section{BAHAN DAN METODE}

Percobaan dilaksanakan di rumah kaca Balai Penelitian Ternak Ciawi (Balitnak), Bogor, Jawa Barat. Rancangan acak lengkap faktorial dengan 10 ulangan digunakan pada percobaan ini. Penelitian dilakukan selama 10 bulan yaitu dari Februari sampai November 2014. Faktor pertama, jenis tanah, yaitu tanah kering masam dan tanah tidak masam (Tabel 1), sedangkan faktor ke dua berupa kultivar rumput benggala. Kultivar rumput benggala yang digunakan adalah kultivar Gatton, Natsuyutaka dan Petrie yang berasal dari kebun koleksi Balitnak. Bahan tanam menggunakan stek, dan ditanam pada pot berdiameter $40 \mathrm{~cm}$ dan tinggi $30 \mathrm{~cm}$. Sebelum ditanam, benih disemai terlebih dahulu di polibag, setelah tanaman umur 1 bulan, kemudian dipindahkan ke pot. Tanah kering masam berasal dari areal perkebunan kelapa sawit di Lolit kambing potong Sei Putih-Sumatera Utara, dan tanah tidak masam yang berasal dari kebun percobaan Balitnak Ciawi. Pemupukan dasar dilakukan menggunakan pupuk buatan, dengan dosis $100 \mathrm{~kg} \mathrm{ha}^{-1}$ urea, $100 \mathrm{~kg} \mathrm{ha}^{-1}$ TSP dan $100 \mathrm{~kg} \mathrm{ha}^{-1} \mathrm{KCl}$, pemupukan diberikan sekali saja sebagai pemupukan dasar pada umur tanaman 1 bulan untuk semua kultivar rumput benggala yang diuji. Penyiraman dilakukan selama 2 hari sekali, dan volume air yang disiramkan disesuaikan dengan kapasitas lapang.

Peubah yang diamati adalah panjang dan lebar daun, panjang ruas, diameter batang, diameter batas ruas, tinggi

Tabel 1. Hasil analisis tanah tidak masam dan tanah kering masam

\begin{tabular}{|c|c|c|c|c|}
\hline Sifat tanah & $\begin{array}{c}\text { Tanah } \\
\text { tidak masam }\end{array}$ & Kriteria & $\begin{array}{c}\text { Tanah kering } \\
\text { masam }\end{array}$ & Kriteria \\
\hline \multicolumn{5}{|l|}{$\mathrm{pH}$} \\
\hline$\left(\mathrm{H}_{2} \mathrm{O}\right)$ & 7.10 & Netral & 4.50 & Masam \\
\hline$(\mathrm{KCl})$ & 6.60 & & 3.80 & \\
\hline \multicolumn{5}{|l|}{ Bahan Organik (\%) } \\
\hline C (Walkley \& Black) & 2.43 & Sedang & 1.56 & Rendah \\
\hline N (Kjedhal) & 0.27 & Sedang & 0.15 & Rendah \\
\hline $\mathrm{C} / \mathrm{N}$ & 9.00 & Sedang & 10.00 & Sedang \\
\hline $\mathrm{P}_{2} \mathrm{O}_{5}(\mathrm{ppm})$ & 464.00 & Tinggi & 68.00 & Tinggi \\
\hline \multicolumn{5}{|c|}{ Nilai Tukar Kation (cmol/kg) } \\
\hline $\mathrm{Ca}$ & 27.73 & Sangat tinggi & 7.73 & Sedang \\
\hline $\mathrm{Mg}$ & 2.48 & Tinggi & 1.32 & Sedang \\
\hline $\mathrm{K}$ & 11.90 & Sangat tinggi & 0.43 & Sedang \\
\hline $\mathrm{Na}$ & 0.17 & Rendah & 0.49 & Sedang \\
\hline KTK $(\mathrm{cmol} / \mathrm{kg})$ & 32.49 & Tinggi & 11.60 & Rendah \\
\hline KB (\%) & $>100$ & Tinggi & 86.00 & Tinggi \\
\hline $\mathrm{Al}^{3+}(\mathrm{cmol} / \mathrm{kg})$ & 0.00 & - & 2.70 & Sedang \\
\hline
\end{tabular}

Keterangan: Hasil analisis Laboratorium Tanah, Balai Penelitian Tanah 
saat muncul bunga, jumlah anakan, bobot segar dan kering hijauan, panjang daun bendera, dan warna hijau daun. Karakter saat fase generatif yang diamati adalah umur bunting, umur saat muncul bunga, umur berbunga sempurna, panjang malai, jumlah spikelet, dan bobot biji, pengamatan pada fase ini diambil dari rataan 3 malai/rumpun. Seluruh peubah yang diamati dilakukan setelah pemangkasan rata (pruning) umur 3 bulan pada rumput benggala. Hijauan dipanen pada umur 40 hari setelah pruning, panen hijauan dilakukan 2 kali. Panen hijauan dilakukan dengan cara memotong rumput setinggi $10 \mathrm{~cm}$ dari permukaan tanah, kemudian ditimbang untuk mengetahui bobot segarnya. Data selanjutnya dianalisis menggunakan program SAS 9.4, apabila terdapat perbedaan maka akan dilanjutkan dengan uji Duncan.

\section{HASIL DAN PEMBAHASAN}

\section{Hasil Analisis Tanah}

Analisis tanah menunjukkan bahwa tanah tidak masam memiliki nilai $\mathrm{pH} 7$ atau sama dengan netral, sedangkan tanah kering masam memiliki nilai $\mathrm{pH}$ tanah 4.5. Tanah masam mengandung $\mathrm{P}$, mineral, KTK dan KB yang rendah, serta mengandung $\mathrm{Al}^{3+}$ tinggi (Tabel 1). Karakter tanah kering masam yang diuji pada penelitian ini memiliki karakteristik sesuai dengan lahan kering masam menurut Mulyani dan Sarwani (2013) yaitu memiliki pH tanah, kapasitas tukar kation (KTK), kejenuhan basa (KB) dan $\mathrm{C}$ organik rendah, kandungan aluminium (kejenuhan $\mathrm{Al}$ ) tinggi, fiksasi P tinggi, peka erosi, dan miskin unsur biotik.

\section{Morfologi dan Produktivitas Rumput Benggala}

Hasil penelitian menunjukkan terdapat interaksi antara jenis kultivar dengan jenis tanah. Lebar daun rumput benggala tertinggi diperoleh pada kultivar Gatton pada tanah kering masam, sedangkan terendah diperoleh pada kultivar Gatton pada lahan kering masam. Karakter panjang daun bendera tertinggi diperoleh pada kultivar Natsuyutaka ditanah kering masam dan terendah juga pada kultivar Natsuyutaka pada tanah kering masam. (Tabel 2). Karakter helai daun pada rumput benggala menjadi salah satu karakter yang penting untuk diperhatikan, karena terdapat korelasi antara lebar daun dengan kandungan NDF (Neutral Ditergent Fiber) dan kecernaan bahan organik, sehingga dapat dijadikan sebagai tahap awal untuk seleksi kualitatif (kualitas nutrisi) genotipe rumput benggala untuk menghasilkan kultivar rumput benggala yang unggul (Batistoti et al., 2012).

Interaksi antara jenis tanah dan kultivar rumput benggala juga berpengaruh terhadap karakter jumlah anakan rumput benggala. Jumlah anakan tertinggi diperoleh pada kultivar Petrie di tanah tidak masam yaitu 35.10 anakan per rumpun, sedangkan terendah diperoleh pada semua kultivar yang ada di tanah kering masam. Penurunan jumlah anakan semua kultivar pada tanah kering masam sekitar $80 \%$. Penurunan jumlah anakan pada tanah kering masam juga terjadi pada padi (Mulyaningsih et al., 2016, Utama, 2010). Jumlah anakan ini berbanding lurus dengan produksi hijauan rumput benggala (Fanindi, 2019), sehingga sangat mempengaruhi produksi hijauan rumput benggala. Produksi bobot segar rumput benggala di tanah kering masam menurun sekitar $85 \%$ dibandingkan pada tanah tidak masam (Tabel 3), sebanding dengan penurunan jumlah anakan pada semua kultivar rumput benggala di tanah kering masam.

Karakter tanaman yang terkait dengan pembungaan dan produksi benih seperti umur mulai berbunga, tinggi tanaman ketika muncul bunga dan produksi biji, dipengaruhi oleh interaksi antara kultivar dengan jenis tanah. Umur mulai berbunga tercepat dicapai oleh kultivar Gatton pada tanah tidak masam, sedangkan terlama dicapai oleh kultivar Natsuyutaka pada lahan tidak masam. Produksi biji rumput benggala tertinggi diperoleh pada kultivar Gatton dan Natsuyutaka pada lahan tidak masam sedangkan terendah diperoleh pada kultivar Petrie pada lahan kering masam. Bobot biji bernas diperoleh pada kultivar Gatton di tanah tidak masam dan terendah pada kultivar Natsuyutaka pada lahan kering masam. Bobot biji bernas kultivar Gatton di tanah kering masam tidak berbeda dibandingkan dengan bobot biji bernas di tanah masam, hal ini diduga karena tidak terjadinya keterlambatan berbunga pada kultivar Gatton di tanah kering masam. Terhambatnya pembungaan diduga berpengaruh terhadap bobot biji bernas kultivar rumput benggala, sebagaimana terjadi pada kultivar Natsuyutaka yang mengalami keterlambatan berbunga di tanah masam, sehingga menyebabkan bobot biji bernasnya di tanah kering masam lebih rendah jika dibandingkan di tanah tidak masam.

Waktu berbunga yang lambat dan rendahnya produksi biji pada kultivar rumput benggala di tanah kering masam dikarenakan adanya pengaruh $\mathrm{Al}$, yang mengakibatkan terjadinya ketidakseimbangan pada nutrisi tanaman, perubahan pada fotosintesis dan kandungan klorofil pada tanaman (Silva, 2012), kemungkinan hal ini yang menyebabkan keterlambatan pembungaan rumput benggala di tanah kering masam. Terlambatnya pembungaan dan rendahnya produksi biji pada kultivar di lahan kering masam juga dimungkinkan karena rendahnya kandungan $\mathrm{P}$ pada tanah kering masam akibat adanya keracunan $\mathrm{Al}$ (Tabel 1), rendahnya P akan mengakibatkan terganggunya pertumbuhan tanaman. Leiser et al. (2012) melaporkan terjadi penurunan pada tinggi tanaman, produksi biji dan keterlambatan pembungaan pada shorgum yang diuji pada kondisi rendah P jika dibandingkan pada tanaman sorghum yang memperoleh nutrisi $P$ yang cukup.

Hasil pengamatan juga menunjukkan bahwa kultivar rumput benggala berpengaruh terhadap semua peubah yang diukur, kecuali pada panjang ruas (Tabel 3). Kultivar Natsuyutaka memiliki panjang daun dan tinggi tanaman saat muncul bunga lebih tinggi jika dibandingkan kultivar Gatton dan Petrie. Kultivar Gatton memiliki karakter diameter batas ruas dan jumlah spikelet yang lebih tinggi jika dibandingkan kedua kultivar lainnya. Kultivar Petrie memiliki karakter lebih rendah hampir pada semua karakter yang diamati dibandingkan kultivar Gatton dan Natsuyutaka.

Respon antara varietas rumput benggala yang berbeda terhadap tanah kering masam bisa terjadi, sebagaimana dilaporkan oleh Silva (2012) bahwa toleransi tanaman 
Tabel 2. Interkasi antara 3 varietas rumput benggala dengan jenis tanah terhadap lebar daun, panjang daun bendera, tinggi saat berbunga,jumlah anakan, umur mulai berbunga, bobot biji, bobot biji bernas dan hampa

\begin{tabular}{|c|c|c|c|}
\hline \multirow{2}{*}{ Jenis tanah } & \multicolumn{3}{|c|}{ Varietas } \\
\hline & Gatton & Petrie & Natsuyutaka \\
\hline & \multicolumn{3}{|c|}{ Lebar daun (cm) } \\
\hline Tidak masam & $1.37 \mathrm{a}$ & $1.09 \mathrm{abc}$ & $1.27 \mathrm{ab}$ \\
\hline \multirow[t]{2}{*}{ Kering masam } & $0.91 \mathrm{c}$ & $1.30 \mathrm{ab}$ & $1.04 b c$ \\
\hline & \multicolumn{3}{|c|}{ Panjang daun bendera $(\mathrm{cm})$} \\
\hline Tidak masam & $21.17 \mathrm{~b}$ & $21.17 b$ & $24.67 \mathrm{a}$ \\
\hline \multirow[t]{2}{*}{ Kering masam } & $19.36 b$ & $22.00 \mathrm{ab}$ & $11.40 \mathrm{c}$ \\
\hline & \multicolumn{3}{|c|}{ Tinggi saat mulai berbunga $(\mathrm{cm})$} \\
\hline Tidak masam & $72.79 \mathrm{~cd}$ & $78.23 \mathrm{bc}$ & $89.50 \mathrm{a}$ \\
\hline \multirow[t]{2}{*}{ Kering masam } & $68.93 \mathrm{~d}$ & $70.76 \mathrm{~d}$ & $82.59 \mathrm{ab}$ \\
\hline & \multicolumn{3}{|c|}{ Jumlah anakan } \\
\hline Tidak masam & $27.20 \mathrm{~b}$ & $35.10 \mathrm{a}$ & $23.90 \mathrm{~b}$ \\
\hline \multirow[t]{2}{*}{ Kering masam } & $7.20 \mathrm{c}$ & $7.30 \mathrm{c}$ & $7.10 \mathrm{c}$ \\
\hline & \multicolumn{3}{|c|}{ Umur mulai berbunga (hari) } \\
\hline Tidak masam & $15.17 \mathrm{~d}$ & $14.83 \mathrm{~d}$ & $22.53 b$ \\
\hline \multirow[t]{2}{*}{ Kering masam } & $17.00 \mathrm{~cd}$ & $18.60 \mathrm{c}$ & $29.87 \mathrm{a}$ \\
\hline & \multicolumn{3}{|c|}{ Bobot biji (g per malai) } \\
\hline Tidak masam & $0.63 \mathrm{a}$ & $0.49 b c$ & $0.68 \mathrm{a}$ \\
\hline \multirow[t]{2}{*}{ Kering masam } & $0.53 b$ & $0.40 \mathrm{c}$ & $0.52 b$ \\
\hline & \multicolumn{3}{|c|}{ Bobot biji bernas (g per malai) } \\
\hline Tidak masam & $0.55 \mathrm{a}$ & $0.32 b$ & $0.52 \mathrm{a}$ \\
\hline \multirow[t]{2}{*}{ Kering masam } & $0.47 \mathrm{a}$ & $0.34 \mathrm{~b}$ & $0.32 b$ \\
\hline & \multicolumn{3}{|c|}{ Bobot biji hampa (g per malai) } \\
\hline Tidak masam & $0.05 \mathrm{~d}$ & $0.07 \mathrm{~cd}$ & $0.12 \mathrm{a}$ \\
\hline Kering masam & $0.07 \mathrm{c}$ & $0.10 \mathrm{~b}$ & $0.08 b c$ \\
\hline
\end{tabular}

Keterangan: Angka yang diikuti huruf yang sama antar semua nilai pada setiap peubah tidak berbeda nyata berdasarkan uji Duncan pada $\alpha=5 \%$

Tabel 3. Karakter panjang daun, panjang ruas, diameter batas ruas, tinggi saat muncul bunga, panjang kuntum bunga dan jumlah spikelet 3 varietas rumput benggala pada tanah kering masam dan tidak masam

\begin{tabular}{|c|c|c|c|c|c|c|c|}
\hline \multirow[b]{2}{*}{ Perlakuan } & \multicolumn{7}{|c|}{ Rata-rata } \\
\hline & $\begin{array}{c}\mathrm{PD} \\
(\mathrm{cm})\end{array}$ & $\begin{array}{c}\text { PR } \\
(\mathrm{cm})\end{array}$ & $\begin{array}{c}\mathrm{DB} \\
(\mathrm{mm})\end{array}$ & $\begin{array}{l}\mathrm{DBR} \\
(\mathrm{mm})\end{array}$ & $\begin{array}{l}\mathrm{TG} \\
(\mathrm{cm})\end{array}$ & $\begin{array}{l}\text { PKB } \\
(\mathrm{cm})\end{array}$ & $\begin{array}{c}\text { JS } \\
\text { (buah) }\end{array}$ \\
\hline \multicolumn{8}{|l|}{ Varietas } \\
\hline Gatton & $31.85 b$ & $14.92 \mathrm{a}$ & $0.21 b$ & $0.20 \mathrm{a}$ & $114.55 b$ & $37.87 \mathrm{a}$ & $28.72 \mathrm{a}$ \\
\hline Petrie & $32.50 \mathrm{~b}$ & $16.26 \mathrm{a}$ & $0.18 \mathrm{c}$ & $0.16 b$ & $114.45 b$ & $32.60 \mathrm{~b}$ & $21.08 b$ \\
\hline Natsuyutaka & $51.40 \mathrm{a}$ & $17.83 \mathrm{a}$ & $0.26 a$ & $0.18 b$ & $127.45 a$ & $40.82 \mathrm{a}$ & $22.00 \mathrm{~b}$ \\
\hline \multicolumn{8}{|l|}{ Tanah } \\
\hline Tidak masam & $39.07 \mathrm{a}$ & $16.61 \mathrm{a}$ & $0.22 \mathrm{a}$ & $0.20 \mathrm{a}$ & $134.77 \mathrm{a}$ & $36.88 \mathrm{a}$ & $23.41 \mathrm{a}$ \\
\hline Masam & $38.10 \mathrm{a}$ & $16.07 \mathrm{a}$ & $0.21 \mathrm{a}$ & $0.17 \mathrm{a}$ & $102.87 b$ & $37.33 \mathrm{a}$ & $24.46 \mathrm{a}$ \\
\hline
\end{tabular}

Keterangan: Angka yang diikuti huruf yang sama pada faktor dan peubah yang sama tidak berbeda nyata berdasarkan uji Duncan pada $\alpha=5 \% . \mathrm{PD}=$ panjang daun; $\mathrm{PR}=$ panjang ruas; $\mathrm{DB}=$ diameter batang; $\mathrm{DBR}=$ diameter batas ruas; $\mathrm{TG}=$ tinggi saat muncul bunga; $\mathrm{PKB}=$ panjang kuntum bunga; JS = jumlah spikelet 
terhadap keracunan Al bervariasi antar spesies. Bahkan genotipe yang berbeda dari spesies yang sama juga menunjukan toleransi yang berbeda terhadap keracunan alumunium (Ma et al., 2014). Karakter panjang daun, panjang ruas, diaemeter batang, diameter batas ruas, panjang kuntum bunga dan jumlah spikelet tidak dipengaruhi oleh jenis tanah, hanya karakter tinggi tanaman pada tanah tidak masam lebih tinggi jika dibandingkan dengan tanah kering masam (Tabel 3). Tinggi tanaman yang lebih rendah pada tanah kering masam, diduga karena adanya pengaruh $\mathrm{Al}$ di dalam tanah kering masam terhadap tanaman, karena $\mathrm{Al}$ akan menghambat fungsi dan pertumbuhan akar sehingga akan menghambat pertumbuhan diatasnya, termasuk tinggi tanaman (Lu et al., 2020). Tinggi tanaman yang lebih rendah juga diduga karena pada tanah kering masam biasanya kekurangan nutrisi dan terjadi keracunan logam seperti $\mathrm{Mn}, \mathrm{Fe}$ dan Al, sehingga akan menghambat pertumbuhan di tanah masam (Bose et al., 2015).

Salah satu tolok ukur produktivitas TPT adalah bobot segar dan kering hijauan TPT. Hasil penelitian menunjukan bahwa bobot segar dan kering hijauan rumput benggala pada panen pertama dipengaruhi oleh jenis kultivar, dimana bobot segar pada kultivar Gatton dan Natsuyutaka lebih tinggi jika dibandingkan dengan kultivar Petrie (Tabel 4), namun pada panen kedua, bobot segar hijauan tidak dipengaruhi oleh jenis kultivar. Karakter warna hijau daun, umur bunting dan umur bunga sempurna dipengaruhi oleh jenis kultivar rumput benggala. Warna hijau daun tertinggi ditunjukan oleh kultivar Gatton, sedangkan umur bunting dan umur bunga sempurna pada kultivar Natsuyutaka lebih panjang jika dibandingkan kultivar Gatton dan Petrie. Hal ini memperkuat bahwa antar kultivar rumput benggala menunjukkan respon yang berbeda pada tanah kering masam, sebagaimana terjadi juga pada padi gogo (Utama, 2010, Mulyaningsih et al., 2016), Rye grass (Silva et al., 2012), gandum (Silva et al., 2012), padi (Zhao et al., 2013) dan kedelai (Kuswantoro et al., 2013).
Jenis tanah berpengaruh terhadap karakter tanaman yang diukur dimana karakter bobot segar, bobot kering dan warna hijau daun pada tanah kering masam, lebih rendah jika dibandingkan pada tanah tidak masam. Karakter umur bunting dan umur bunga sempurna pada tanah kering masam, lebih lama pada tanah kering masam jika dibandingkan pada tanah tidak masam. Rendahnya produksi pada tanah kering masam dipengaruhi oleh keberadaan Al yang terdapat pada tanah masam, keracunan Al akan mengakibatkan terhambatnya perkembangan dan pertumbuhan akar (Muhammad et al., 2018), mempengaruhi fotosintesis dan respirasi (Peixoto et al., 2002), sehingga akan mempengaruhi metabolisme tanaman dan pada akhirnya akan menurunkan hasil panen (Lu et al., 2020). Selain itu keracunan Al juga akan mengakibatkan terjadinya ketidak seimbangan penyerapan unsur hara, seperti $\mathrm{Ca}, \mathrm{Mg}, \mathrm{P}$ dan $\mathrm{K}$ (Olivares et al., 2009), ketidakseimbangan ini akan mengakibatkan produktivitas tanaman menjadi lebih rendah. Penurunan produksi tanaman pada lahan masam juga terjadi pada kedelai (Kuswantoro et al., 2013), jagung (Nursyamsi et al., 2016, Wang et al., 2015) dan padi gogo (Utama, 2010).

Hasil keragaan morfologi kultivar rumput benggala yang rendah pada tanah kering masam pada penelitian ini akibat keracunan $\mathrm{Al}$ dapat dilihat dari keragaan akar rumput benggala pada penelitian ini (Gambar 1). Toleransi Al pada tanaman selama ini dapat dilihat dari akar tanaman, karena Al akan berpengaruh langsung terhadap akar, terutama menghambat pada pertumbuhan dan perkembangan akar pada hampir semua spesies (Silva, 2012). Pengaruh Al terhadap pertumbuhan akar rumput juga dinyatakan oleh Arroyave et al. (2013) yang menyatakan bahwa terjadi penghambatan pada akar rumput $B$. brizantha dan $B$. ruziziensis. Keragaan akar rumput benggala pada tanah kering masam untuk setiap kultivar yang diuji, lebih kecil jika dibandingkan dengan kondisi akar di tanah tidak masam (Gambar 1). Hasil keragaan morfologi dan kondisi akar kultivar rumput benggala pada tanah kering masam

Tabel 4. Bobot segar,bobot kering, hijau daun, umur bunting dan bunga sempurna 3 varietas rumput benggala pada tanah kering masam dan tidak masam

\begin{tabular}{|c|c|c|c|c|c|c|c|}
\hline \multirow[b]{2}{*}{ Perlakuan } & \multicolumn{7}{|c|}{ Rata-rata } \\
\hline & $\begin{array}{c}\text { BS } 1 \\
\text { (g per } \\
\text { rumpun) }\end{array}$ & $\begin{array}{c}\text { BS } 2 \\
\text { (g per } \\
\text { rumpun) }\end{array}$ & $\begin{array}{c}\text { BK } 1 \\
\text { (g per } \\
\text { rumpun) }\end{array}$ & $\begin{array}{c}\text { BK } 2 \\
\text { (g per } \\
\text { rumpun) }\end{array}$ & $\begin{array}{l}\text { Hijau } \\
\text { daun }\end{array}$ & $\begin{array}{c}\text { UB } \\
\text { (hari) }\end{array}$ & $\begin{array}{c}\text { UBS } \\
\text { (hari) }\end{array}$ \\
\hline \multicolumn{8}{|l|}{ Varietas } \\
\hline Gatton & $50.15 a$ & $72.98 \mathrm{a}$ & $13.71 \mathrm{a}$ & $20.99 b$ & $8.43 a$ & $14.35 b$ & $23.69 b$ \\
\hline Petrie & $38.97 b$ & $75.44 \mathrm{a}$ & $10.96 \mathrm{~b}$ & $19.96 b$ & $4.80 \mathrm{~b}$ & $14.27 b$ & $23.52 b$ \\
\hline Natsuyutaka & $50.94 \mathrm{a}$ & $82.47 \mathrm{a}$ & $15.28 \mathrm{a}$ & $24.90 \mathrm{a}$ & $6.50 \mathrm{ab}$ & $24.22 \mathrm{a}$ & $34.33 \mathrm{a}$ \\
\hline \multicolumn{8}{|l|}{ Tanah } \\
\hline Tidak Masam & $83.99 a$ & $136.48 \mathrm{a}$ & $23.77 \mathrm{a}$ & $39.06 \mathrm{a}$ & $7.24 \mathrm{a}$ & $15.71 b$ & $25.01 b$ \\
\hline Masam & $9.38 b$ & $17.43 b$ & $2.87 \mathrm{~b}$ & $4.38 b$ & $5.90 \mathrm{~b}$ & $19.51 \mathrm{a}$ & $29.34 \mathrm{a}$ \\
\hline
\end{tabular}

Keterangan: Angka yang diikuti huruf yang sama pada faktor dan peubah yang sama tidak berbeda nyata berdasarkan uji duncan pada $\alpha=$ $5 \%$. BS1 = Bobot segar panen pertama; BS2 = Bobot segar panen ke dua; BK1 = bobot kering; BK2 = bobot kering 2; UB = umur bunting; UBS = umur bunga sempurna 
yang menurun jika dibandingkan kultivar pada tanah tidak masam, menunjukkan bahwa ketiga kultivar ini kurang toleran terhadap tanah kering masam, sehingga perlu dicari lagi kultivar-kultivar rumput benggala toleran pada tanah kering masam, dengan cara eksplorasi atau melakukan penelitian pemuliaan untuk membentuk kultivar rumput benggala toleran pada tanah kering masam.

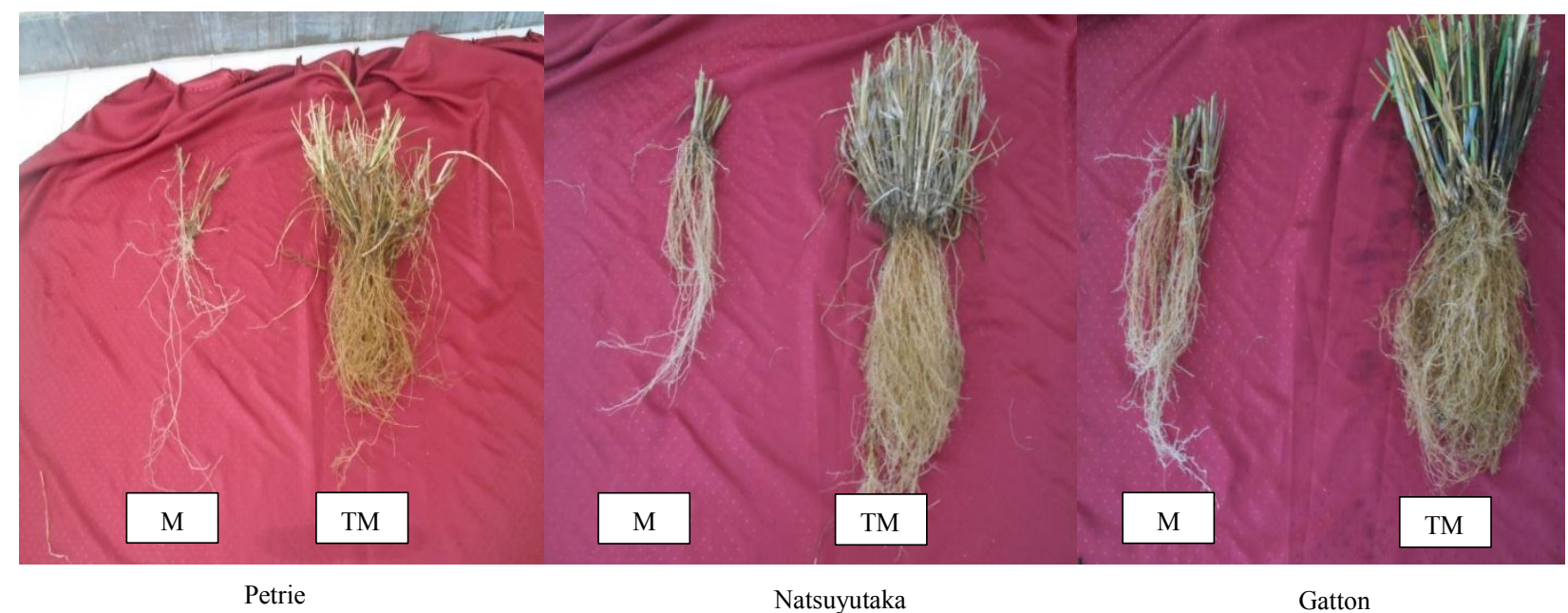

Gambar 1. Keragaan akar kultivar rumput benggala kultivar Petrie, Natsuyutaka dan Gatton pada tanah kering masam (M) dan tanah tidak masam (TM)

\section{KESIMPULAN}

Karakter tinggi tanaman, hijau daun, umur bunting, umur berbunga sempurna, bobot segar dan kering hijauan pada tanah kering masam lebih rendah jika dibandingkan karakter tanaman pada tanah tidak masam. Bobot hijauan merupakan tolak ukur produktivitas TPT, bobot hijauan kultivar rumput benggala yang diuji menurun $80 \%$ di tanah kering masam jika dibandingkan bobot hijauannya di tanah tidak masam. Peubah penting kultivar rumput benggala yang diuji seperti bobot segar dan kering hijaun serta jumlah anakan menurun pada tanah kering masam, hal ini menunjukkan bahwa kultivar yang diuji tidak toleran pada tanah kering masam.

\section{DAFTAR PUSTAKA}

Almeida, A.A.S., F.A. Monteiro, L. Jank 2000. Avaliação de Panicum maximum jacq. para tolerância ao alumínio em solução nutritiva. R. Bras. Ci. Solo, 24:339-344.

Arroyave, C., R. Tolrà, T. Thuy, J. Barceló, C. Poschenrieder. 2013. Differential aluminum resistance in Brachiaria species. Environ. Exp. Bot. 89: 11-18.

Batistoti, C., B. Lempp, L. Jank, M. das G. Morais, A.C. Cubas, R.A. Gomes, M.V.B. Ferreira. 2012. Correlations among anatomical, morphological, chemical and agronomic characteristics of leaf blades in Panicum maximum genotypes. Anim. Feed Sci. Technol. 171:173-180.
Bose, J., O. Babourina, Y. Ma, M. Zhou, S. Shabala, S, Z. Rengel. 2015. Specificity of ion uptake and homeostasis maintenance during acid and aluminium stresses. p. 229-25. In S. K. Panda, F. Baluska (Eds.). Aluminum Stress Adaptation in Plants. Signaling Communication in Plants. Cham: Springer International Publishing. Cham, 6330 Switzerland.

Efendi, R., Y. Musa, M.F. Badri, M.D. Rahim, M. Azrai, M. Pabendon. 2015. Seleksi jagung inbrida dengan marka molekuler dan toleransinya terhadap kekeringan dan nitrogen rendah. J. Penelitian Pertanian Tanaman Pangan. 34:43-53.

Fanindi, A., S.H. Sutjahjo, S.I. Aisyah, N.D. Purwantari. 2019. Morphological characteristics and productivity of guinea grass (Panicum maximum CV Purple Guinea) irradiated with gamma-ray. Trop. Anim. Sci. J. 42:97-105.

Fernandes, F.D., A.K.B. Ramos, L. Jank, M.A. Carvalho, G.B. Martha Jr, G.J. Braga. 2014. Forage yield and nutritive value of Panicum maximum genotypes in the Brazilian savannah. Sci. Agric.71:23-29.

Hare, M.D., S. Phengphet, T. Songsiri, N. Sutin. 2014. Botanical and agronomic growth of two Panicum maximum cultivars, Mombasa and Tanzania, at varying sowing rates. Trop. Grasslands. 22:246-253. 
Jank, L., J.A. Martuscello, R.M.S. Resende, C.B. Valle. 2010. Panicum maximum Jacq. p. 166-195. In Fonseca DM and Martuscello JA (Eds.) Plantas Forrageiras. Editora UFV, Vicosa, BR.

Kochian, L.V., M.A. Piñeros, O.A. Hoekenga. 2005. The physiology, genetics and molecular biology of plant aluminum resistance and toxicity. Plant Soil 274: 175-195.

Kuswantoro, H., D.M. Arsyad, Purwantoro. 2013. Karakteristik kedelai toleran lahan kering masam. Buletin Palawija 25:1-10.

Leiser, W.L., H.F. Rattunde, H.P. Piepho, E. Weltzien, A. Diallo, A.E. Melchinger, H.K. Parzies, B.I. Haussmann. 2012. Selection strategy for sorghum targeting phosphorus-limited environments in West Africa: Analysis of multi-environment experiments. Crop Sci. 52:2517-2527.

Lu., H.L., Ge. Dong, H. Hua, W.R. Zhao, J.Y. Li, R.X. Xu. 2020. Method for initially selecting Al-tolerant rice varieties based on the charge characteristics of their roots. Ecotoxicol. Environ. Safety 187:1-8.

Ma, J.F., Z.C. Chen, R.F. Shen. 2014. Molecular mechanisms of Al tolerance in gramineous plants. Plant Soil 381: $1-12$.

Muhammad, N., G. Zvobgo, G.P. Zhang. 2018. A review: the beneficial effect of aluminum on plant growth in acid soil and the possible mechanisms. J. Integrative Agric. 18:1518-1528.

Mulyani, A., M. Sarwani. 2013. Karakteristik dan potensi lahan sub optimal untuk pengembangan pertanian di Indonesia. J. Sumberdaya Lahan 7:47-55.

Mulyaningsih, E.S., A.Y. Perdani, S. Indrayani, Suwarno. 2016. Seleksi fenotipe populasi padi gogo untuk hasil tinggi, toleran aluminium dan tahan blas pada tanah masam. J. Penelitian Pertanian Tanaman Pangan 35:191-197.

Nursyamsi, D., M. Osaki, T. Tadano. 2016. Mechanism of aluminum toxicity avoidance in tropical rice (Oryza sativa), maize (zea mays), and soybean (Glycine max). Indonesian J. Agric. Sci. 3:12-24.

Olivares, E., E. Pena, E. Marcano, J. Mostacero, G. Aguiar, M. Benitez, M.E. Rengifo. 2009. Aluminum accumulation and its relationship with mineral plant nutrients in 12 Pteridophytes from Venezuela. Environ. Exp. Bot. 65:132-141.

Peixoto, P.H.P., F.M. Da Matta, J. Cambraia. 2002. Responses of the photosynthetic apparatus to aluminum stress in two sorghum cultivars. J. Plant Nutr. 25:821-832.

Silva, S. 2012. Aluminium toxicity targets in plants. J. Bot. 2012:1-8.

Silva, S., C.ã. Santos, M. Matos, O.P. Carnide. 2012. Al toxicity mechanism in tolerant and sensitive rye genotypes. Environ. Exp. Bot. 75:89-97.

Silva, S., E. Rodriguez, O.P. Carnide, P.M. Lopes, M. Matos, H.G. Pinto, C.ão Santos. 2012. Zonal responses of sensitive vs. tolerant wheat roots during Al exposure and recovery. J. Plant Physiol. 169:760- 769.

Utama, M.J.H. 2010. Penapisan varietas padi gogo toleran cekaman aluminium. J. Agron. Indonesia 38:163169.

Wang, C., M.M. Zheng, A.Y. Hu. 2018. Diazotroph abundance and community composition in an acidic soil in response to aluminum-tolerant and aluminumsensitive maize (Zea mays L.) cultivars under two nitrogen fertilizer forms. Plant Soil 424:463-478.

Wang, L., X.W. Fan, J.L. Pan, Z.B. Huang, Y.Z. Li. 2015. Physiological characterization of maize tolerance to low dose of aluminum, highlighted by promoted leaf growth. Planta 242:1391-1403.

Xu, L.M., C. Liu, B.M. Cui, N. Wang, Z. Zhao, L.N. Zhou, K.F. Huang, J.Z. Ding, H.M. Du, W. Jiang, S.Z. Zhang. 2018. Transcriptomic responses to aluminum (Al) stress in maize. J. Integr. Agric. 17:1946-1958.

Yang, Z.B., D. Eticha, A. Albacete, I.M. Rao, T. Roitsch, W.J. Horst. 2012. Physiological and molecular analysis of the interaction between aluminium toxicity and drought stress in common bean (Phaseolus vulgaris). J. Exp. Bot. 63:3109-3125.

Zhao, X.Q., S.W. Guo, F. Shinmachi, M. Sunairi, A. Noguchi, I. Hasegawa, R.F. Shen. 2013. Aluminium tolerance in rice is antagonistic with nitrate preference and synergistic with ammonium preference. Ann. Bot. 111:69-77. 